Original Research

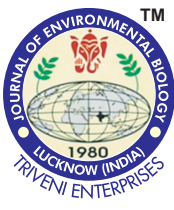

DOI : http://doi.org/10.22438/jeb/40/2/MRN-854

\title{
Use of bacterial endospore with longer shelf-life in improved retting of jute
}

\begin{tabular}{lll}
\hline Paper received: 06.02.2018 Revised received: 28.05.2018 Re-revised received: $27.06 .2018 \quad$ Accepted: 13.08 .2018
\end{tabular}

\section{Authors Info \\ L. Chattopadhyay, B. Majumdar*, S.P. Mazumdar, A.R. Saha, R. Saha and S. Barai Division of Crop Production, ICAR-Central Research Institute for Jute \& Allied Fibres, Barrackpore, Kolkata- 700 120, India \\ *Corresponding Author Email : bmajumdar65@gmail.com}

\section{Edited by \\ Dr. B. Bhusan Mishra}

\section{Reviewed by}

Dr. Devendra Mani Tripathi

Dr. Subhranshu Nayak

\section{Abstract}

Aim : The aim of the present study was to evaluate the retting of jute (Corchorus olitorius $L$. and $C$. capsularis L.) using the endospores of microbial consortium of three strains of Bacillus pumilus with extended shelf-life.

Methodology : Endospore and vegetative cells of Bacillus pumilus were tested for viability by introducing them into different temperature, $\mathrm{pH}, \mathrm{UV}$ radiation and antibiotics. Laboratory, as well as field-trials of jute retting was performed with 6 and 18-months-old endospores and vegetative cells of Bacillus pumilus with estimation of enzymatic activities for comparison of their retting efficiency.

Results: Endospores of Bacillus pumilus recorded very high colony forming unit $\left(10^{9}\right.$ to $10^{8} \mathrm{ml}^{-1}$ ) compared to their vegetative cells $\left(10^{6}\right.$ to $\left.10^{4} \mathrm{ml}^{-1}\right)$ after 6 to 18 months of their preservation. Endospores also showed higher resistance to temperature, $\mathrm{pH}, \mathrm{UV}$ irradiation and antibiotic than their vegetative forms. High colony forming unit and higher release of pectinolytic and xylanolytic enzymes during retting of jute by endospores resulted in complete of jute retting in 10 days with good quality jute fibre compared to talc based formulation.

Interpretation: It can be concluded from the study that endospores remained highly efficient in rejuvenating higher

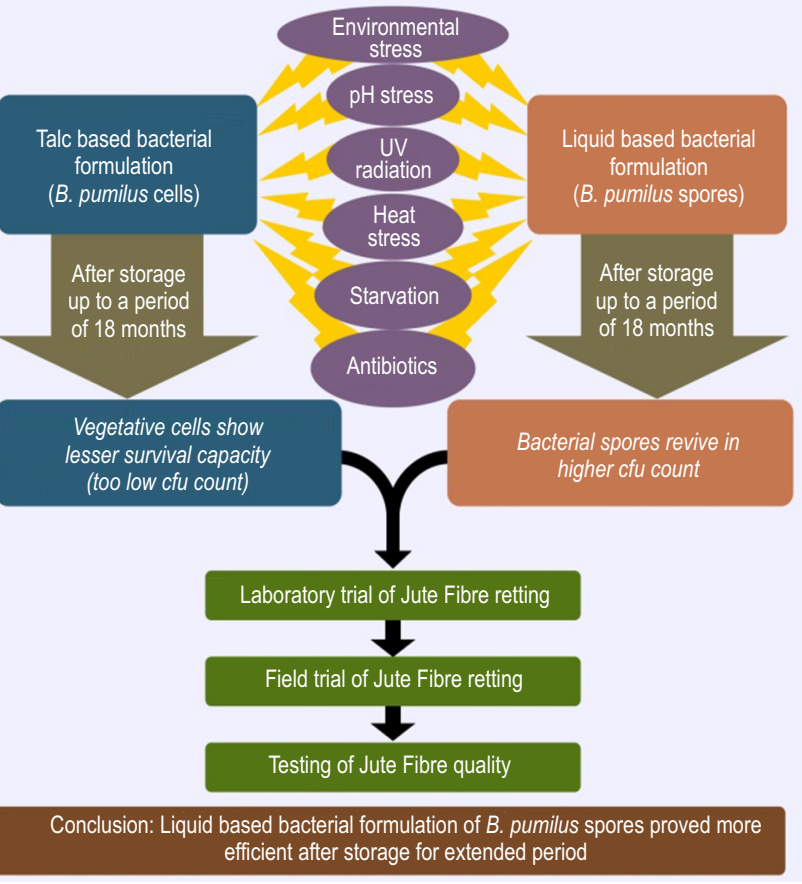

CFU and quantitatively larger pool of enzymes to accelerate retting of jute after prolonged preservation. Therefore, the endospores of Bacillus pumilus can be used cost effectively in place of their talc based formulation for higher shelf life of the product, faster retting and better fibre quality of jute.

Key words: Bacillus pumilus, Carrier based inoculants, Endospore, Jute retting, Shelf-life.

How to cite: Chattopadhyay, L., B. Majumdar, S.P. Mazumdar, A.R. Saha, R. Saha and S. Barai : Use of bacterial endospore with longer shelf-life in improved retting of jute. J. Environ. Biol., 40, 245-251 (2019). 


\section{Introduction}

Jute retting involves controlled decomposition of the nonfibrous materials (pectin, hemicelluloses etc.) with the help of enzymes secreted by aquatic microbes. Although jute retting is better in slow moving soft water, only $10 \%$ of jute growers of India have access to this and the remaining $90 \%$ ret their harvest in stagnant water bodies like lakes, ditches and ponds. Use of microbial inoculants to hasten the jute retting in stagnant water retting has been reported by several workers (Banik et al., 2007; Das et al., 2012; Das et al., 2015; Das et al., 2018). The major drawback in using the carrier based microbial inoculants either as biofertilizer/ biopesticides or bioformulation is their short shelf life, as the microbial cells cannot withstand environmental stress for prolonged period. In most of the cases, the shelf life of solid carrier based inoculant is about six months, which can be extended up to two years by making liquid formulation (Mahdi et al., 2010; Pindi and Satyanarayana, 2012).

Endospores of various Bacillus species are formed during sporulation, a process that is generally induced by reduced levels of nutrients, high mineral composition, neutral $\mathrm{pH}$ temperature and high cell density in the environment (Sella et al., 2014). Sporulation generates a non-reproductive, dormant structure which can survive for extended periods with little or no nutrients. Endospores have very different structural and chemical composition than that of a growing cell (Mohammadi and Sohrabi, 2012). They have thick spore like structure with exosporium, spore coat, cortex and core wall, and exhibit a high degree of resistance to ionizing $(\mathrm{V})$ radiation, UV radiation, dry and wet heat and various chemicals that can cause DNA damage. These properties are achieved because of their low water content, presence of dipicolinic acid (5-15\% of spore dry weight) and a group of small acid soluble spore proteins (SASP of $\alpha / \beta$ type). Bacteria spores, despite being metabolically dormant, have remarkable capacity to detect nutrients and other molecules in their environment through a biochemical sensory apparatus which can trigger spore germination to vegetative cells within minutes of exposure of germinants (Thirumurugan and Asha, 2010).

Use of talc based pectinolytic microbial formulation was successfully demonstrated for faster retting of jute and fibre quality improvement across the jute growing states of India (Majumdar et al., 2013; Majumdar and Satpathy, 2014). The talc based microbial formulation consisted of three strains of Bacillus pumilus viz., Bacillus pumilus IMAU80221; Bacillus pumilus GVC 11 and Bacillus pumilus SYBC-W (Das et al., 2015). In the present study, an attempt was made to increase the shelf life of microbial consortium by using their endospores for accelerating the retting process and fibre quality improvement.

\section{Materials and Methods}

Endospore preparation: Endospores were prepared by cultivating three strains of Bacillus pumilus. Bacillus pumilus IMAU80221 (MTCC 5573), Bacillus pumilus GVC 11 (MTCC
5574) and Bacillus pumilus SYBC-W (MTCC 5575) cells were taken separately in $500 \mathrm{ml}$ Erlenmeyer flasks with $100 \mathrm{ml}$ sporulation broth medium ( $\mathrm{pH}-7.6)$. The sporulation broth medium composed of sporulation broth $15.8 \mathrm{~g} \mathrm{l}^{-1}$ (Hi-Media, Mumbai, India), $1 \mathrm{ml}$ each of $0.05 \% \mathrm{MgSO}_{4} \cdot 7 \mathrm{H}_{2} \mathrm{O}, 0.2 \% \mathrm{KCl}$ and $1 \mathrm{M} \mathrm{Ca}\left(\mathrm{NO}_{3}\right)_{2}, 0.01 \mathrm{M} \mathrm{MnCl}_{2}$ and $1 \mathrm{mM} \mathrm{FeSO}_{4}$. Batch cultures were incubated at $34^{\circ} \mathrm{C}$ in rotary shaker at $150 \mathrm{rpm}$.

Bacterial growth was monitored via optical density measurements at $600 \mathrm{~nm}$, using UV-visible spectrophotometer and sporulation was checked by a phase contrast microscope (EVOS XL CORE, Thermo Fisher Scientific). Endospores were harvested when they accounted for at least $90 \%$ of total population (generally on the $4^{\text {th }}$ day), and stored at $4^{\circ} \mathrm{C}$ in sterile distilled water (Nicholson and Setlow, 1990). To germinate the bacterial spores into vegetative cells, pectin agar medium $(\mathrm{pH} 8)$ was used containing $1 \%$ citrus pectin, $0.5 \%$ peptone, $0.5 \% \mathrm{NaCl}$, $0.02 \% \mathrm{MnSO}_{4}, 0.04 \% \mathrm{KH}_{2} \mathrm{PO}_{4}$ and $2 \%$ agar powder.

Viability count of talc-based microbial formulation and endospores: After six and eighteen months of preparation, the viability of spores in suspension and bacterial cells in carrierbased microbial formulation was checked by serial dilution method. Microbial formulation and spore suspensions were serially diluted in sterile distilled water and plated on pectin agar plates, incubated for $48 \mathrm{hr}$ at $34^{\circ} \mathrm{C}$, and then the CFUs were counted using a digital colony counter.

Monitoring of $\mathrm{pH}$ resistance of bacterial cells and endospores: To monitor the degree of $\mathrm{pH}$ resistance, pectin agar media plates with $\mathrm{pH}$ values $3,8,10$ and 12 were prepared. A $100 \mu \mathrm{l}$ of three different types of endospores and their respective bacterial cells were plated on pectin agar plates with varying $\mathrm{pH}$ and incubated for $48 \mathrm{hr}$ at $34^{\circ} \mathrm{C}$. After incubation, CFUs were counted with a digital colony counter.

Monitoring temperature resistance: To study the temperature resistance, $1 \mathrm{ml}$ each of bacterial cells and endospores were incubated at 60,80 and $100^{\circ} \mathrm{C}$, respectively, for 15 min using water bath. The bacterial cells and endospores were then incubated for $48 \mathrm{hr}$ at $34^{\circ} \mathrm{C}$ on pectin agar plates. After completion of incubation, CFUs were counted with a digital colony counter.

Monitoring viability in UV radiation: To monitor the resistance to UV radiation, a $100 \mu \mathrm{l}$ each of bacterial cells and endospores were placed on pectin agar plates and exposed under UV light $(254 \mathrm{~nm})$ for 10, 15, 20 and $30 \mathrm{~min}$, respectively. The UV exposed plates were then incubated for $48 \mathrm{hr}$ at $34^{\circ} \mathrm{C}$. After completion of incubation, CFUs were counted with a digital colony counter.

Antibiotic sensitivity test: The antibiotics viz., streptomycin tetracycline, ampicillin and amoxicillin were used at concentrations of $5,10,30,60,120$ and $240 \mathrm{\mu gml}^{-1}$. To detect the antibiotic susceptibility of endospores, $1 \mathrm{ml}$ each of the spore suspension was centrifuged and the pellet was resuspended again with $1 \mathrm{ml}$ each of the said concentrations of 
antibiotics and then incubated overnight at $4^{\circ} \mathrm{C}$. After incubation, a $100 \mu$ l of each spore suspension were spread over pectin agar plates to view the endospore population. The susceptibility of bacterial cells was also checked with antibiotic strips (Hi Media) of the said concentrations.

Small scale retting: Six month old spore suspensions and their vegetative cells in talc based formulation with a combination of 1:2:1 v/v for MTCC 5573, MTCC 5574 and MTCC 5575 were used for retting of jute plants, as this combination had been reported previously for highest activities of polygalacturonase, pectin lyase and xylanase enzymes (Das et al., 2015). For each set, one kilogram of whole jute plant was immersed into 10 I sterile pond water. In Set 1, $4 \mathrm{ml}$ of spore formulation (1:2:1 v/v with a CFU $\left.10^{9} \mathrm{ml}^{-1}\right)$ and in Set 2, $2 \mathrm{ml}(1: 2: 1 \mathrm{v} / \mathrm{v}$ with a CFU $10^{9} \mathrm{ml}^{-1}$ ) of spore formulation was added. Set 3 contained $2 \mathrm{~g}$ of regular talc-based microbial formulation. The study was replicated thrice for statistical validation.

Large scale retting: After preservation of bacterial spores and talc based formulation for 18 months, a large scale field trial was carried out in triplicate with whole jute plants, grown under standard field conditions, in a set of three large concrete retting tanks. Whole jute plants, after harvesting, were kept for leaf shedding and then $450 \mathrm{~kg}$ of it was immersed in each retting tank containing 4500 I of underground water. Bacterial spore suspensions were used with a combination same as applied in laboratory scale study. A $1.8 \mathrm{l}$ and $900 \mathrm{ml}$ of spore suspension was used in tank I and tank II, respectively, while $900 \mathrm{~g}$ of talc based formulation was used in tank III.

Enzyme activity assays of retting liquor: Polygalacturonase and xylanase activities were measured and CFU counts were monitored throughout the retting process after collection of retting liquor samples from small and large scale retting trials. Extracellular polygalacturonase was measured by DNS method (Phutela et al., 2005) and that of xylanase by reducing sugar estimation method using 3, 5 dinitro salicylic acid (Manisha etal., 2009).

Retting water samples after serial dilution, pour-plated on pectin agar plates to monitor the growth of pectinolytic bacteria. Similarly, xylanolytic isolates were estimated by plating retting water samples in xylan agar $(0.5 \%$, xylan, $0.5 \%$ yeast extract, $0.5 \% \mathrm{NaCl}, 2 \%$ agar, at $\mathrm{pH} 8.0$ ). The plates were incubated for $72 \mathrm{hrs}$ at $34^{\circ} \mathrm{C}$ and then colonies were counted by a digital colony counter.

Fibre quality testing: After completion of retting, fibre samples were extracted, washed with clean water and then dried under the sun to record the dry weight of fibre. The fibre samples were processed and then the bundle fibre strength was measured following the method of Roy et al. (2009), and fibre fineness by airflow method of Bandyopadhyay and Sinha (1968).

Statistical analysis: The data were analysed by using Sigma plot 11.0 for estimating the standard deviations.

\section{Results and Discussion}

The endospores of three strains of Bacillus pumilus maintained their CFU number after 6 months of storage at $4^{\circ} \mathrm{C}$. The CFU of endospores ranged between 11 to $20 \times 10^{9} \mathrm{ml}^{-1}$ after 6 months compared to their initial CFU of 25 to $32 \times 10^{9} \mathrm{ml}^{-1}$. The CFU count decreased marginally after 18 months of storage to 16 to $18 \times 10^{8} \mathrm{ml}^{-1}$. On the other hand, the CFU count of the vegetative forms of Bacillus pumilus in talc based formulation decreased drastically from initial CFU of $12 \times 10^{10} \mathrm{ml}^{-1}$ to $14 \times 10^{6} \mathrm{ml}^{-1}$ after 6 months and $23 \times 10^{4} \mathrm{ml}^{-1}$ after 18 months of storage, respectively. The difference in structural and chemical composition and over all, the metabolic state of the spores from corresponding vegetative cells provided them the distinct resistance power against environmental stress (Sella et al., 2014) which eventually helped them to survive for longer period of time as in this case. Higher shelf life of spores in hydrated condition was also reported by Stelow (2007) and Leggett et al. (2012).

Endospores of $B$. pumilus also showed higher level of $\mathrm{pH}$ tolerance compared to their vegetative forms (Table 3 ). After incubation, endospores showed higher growth at $\mathrm{pH} 8$ and $\mathrm{pH} 10$, moderate growth at $\mathrm{pH} 3$ and $\mathrm{pH} 12$; whereas, their vegetative forms grew well only at $\mathrm{pH}$ ranging between $\mathrm{pH} 8$ to 10 , while no growth was observed for vegetative cells at very low $\mathrm{pH}(\mathrm{pH} 3$ ) and very high $\mathrm{pH}$ (12). The inner membrane of endospores composed of lipids that acted as impermeable layer to small molecules, including water, which might have protected the core from various chemicals (Paredes-Sabja et al., 2011; Leggett et al., 2012). This in turn also helped the spores to survive at a wider $\mathrm{pH}$ range.

The data in Table 3. clearly indicates that bacterial endospores were quite able to withstand higher temperatures (moist heat) than their vegetative counterparts. For all three bacterial spores, the number of colonies per plate was $>300$ even after $15 \mathrm{~min}$ of incubation at $100^{\circ} \mathrm{C}$, whereas their vegetative cells could only withstand lower temperatures $\left(60^{\circ} \mathrm{C}\right.$ and $80^{\circ} \mathrm{C}$ ). Bacterial cells did not propagate suitably when introduced into boiling water bath, and counted less than $10 \%$ of the spores at $100^{\circ} \mathrm{C}$. The addition of divalent ions like $\mathrm{Ca}^{2+}, \mathrm{Mg}^{2+}$ and $\mathrm{Mn}^{2+}$ in the sporulation media might have increased the wet heat resistance of the endospores of $B$. pumilus by affecting the peptidoglycan composition and core dehydration (Atrih and Foster, 2001; Cazemier et al., 2001; Hornstra et al., 2009) compared to their vegetative cells. Occurrence of large amounts of SASPs in the core of endospores resulted in binding of these proteins to the DNA of endospores and these SASPs prevented the breakdown of DNA at high temperature by physical shielding (Nicholson et al., 2000).

Endospores and bacterial cells of $B$. pumilus were exposed to UV radiation, respectively, for 10,15 and $20 \mathrm{~min}$. The result presented in Table 3 . clearly states that the UV radiation had affected the vegetative cells and spores, but severe damage was noticed on vegetative cells compared to their corresponding 
Table 1 : Changes in pectinolytic and xylanolytic bacterial population and polygalacturonase and xylanase enzyme activities in laboratory scale study of jute retting

\begin{tabular}{|c|c|c|c|c|c|}
\hline Days of retting & Day 1 & Day 5 & Day 7 & Day 10 & Day 12 \\
\hline \multicolumn{6}{|c|}{ Pectinolytic bacteria (CFU ml') } \\
\hline Set 1 & $33 \times 10^{3}$ & $180 \times 10^{7}$ & $54 \times 10^{10}$ & $147 \times 10^{12}$ & $52 \times 10^{13}$ \\
\hline Set 2 & $28 \times 10^{3}$ & $55 \times 10^{5}$ & $34 \times 10^{5}$ & $21 \times 10^{8}$ & $46 \times 10^{9}$ \\
\hline Set 3 & $32 \times 10^{3}$ & $51 \times 10^{5}$ & $11 \times 10^{7}$ & $10 \times 10^{8}$ & $25 \times 10^{9}$ \\
\hline \multicolumn{6}{|c|}{ Xylanolytic bacteria (CFU mll') } \\
\hline Set 1 & $25 \times 10^{3}$ & $44 \times 10^{7}$ & $58 \times 10^{9}$ & $90 \times 10^{11}$ & $67 \times 10^{13}$ \\
\hline Set 2 & $41 \times 10^{3}$ & $48 \times 10^{5}$ & $78 \times 10^{6}$ & $92 \times 10^{8}$ & $16 \times 10^{10}$ \\
\hline Set 3 & $23 \times 10^{3}$ & $20 \times 10^{5}$ & $11 \times 10^{7}$ & $25 \times 10^{8}$ & $72 \times 10^{10}$ \\
\hline \multicolumn{6}{|c|}{ Polygalacturonase activity $\left(\mathrm{U} \mathrm{ml}^{-1}\right)$} \\
\hline Set 1 & 0 & $20.8 \pm 0.612$ & $48.55 \pm 1.65$ & $93.64 \pm 0.343$ & $104.04 \pm 1.09$ \\
\hline Set 2 & 0 & $12.71 \pm 0.49$ & $28.09 \pm 1.22$ & $50.86 \pm 0.52$ & $58.95 \pm 1.8$ \\
\hline Set 3 & 0 & $3.46 \pm 0.494$ & $11.56 \pm 0.598$ & $21.96 \pm 1.3$ & $31.21 \pm 0.37$ \\
\hline \multicolumn{6}{|c|}{ Xylanase activity $\left(\mathrm{U} \mathrm{ml}^{-1}\right)$} \\
\hline Set 1 & 0 & $10.4 \pm 0.524$ & $18.49 \pm 0.88$ & $36.99 \pm 0.68$ & $50.86 \pm 0.88$ \\
\hline Set 2 & 0 & $4.62 \pm 0.26$ & $8.09 \pm 0.15$ & $20.81 \pm 1.61$ & $30.06 \pm 0.79$ \\
\hline Set 3 & 0 & $1.16 \pm 0.09$ & $3.47 \pm 0.21$ & $8.09 \pm 0.14$ & $12.72 \pm 0.66$ \\
\hline
\end{tabular}

Values are mean $\pm \mathrm{SD}$ in each row for particular set

Table 2 : Effect of endospores and talc based formulation of Bacillus pumilus on retting duration, fibre recovery, fibre strength and fibre fineness of jute

\begin{tabular}{|c|c|c|c|c|}
\hline Test set & Fibre strength (gtex $\left.{ }^{-1}\right)$ & Fibre fineness (tex) & Retting duration (days) & Fibre recovery $(\%)$ \\
\hline \multicolumn{5}{|c|}{ Laboratory scale (After 6 months of storage) } \\
\hline Set 1 & $27.80 \pm 2.21$ & $2.40 \pm 0.11$ & 10 & 7.2 \\
\hline Set 2 & $25.71 \pm 0.59$ & $2.54 \pm 0.44$ & 12 & 6.8 \\
\hline Set 3 & $25.11 \pm 0.94$ & $2.61 \pm 0.05$ & 15 & 6.2 \\
\hline \multicolumn{5}{|c|}{ Field study (After 18 months of storage) } \\
\hline Set 1 & $27.60 \pm 1.65$ & $2.51 \pm 0.16$ & 10 & 7.3 \\
\hline Set 2 & $25.60 \pm 1.38$ & $2.62 \pm 0.13$ & 12 & 6.9 \\
\hline Set 3 & $21.80 \pm 1.22$ & $2.84 \pm 0.10$ & 21 & 5.5 \\
\hline
\end{tabular}

Values are mean \pm SD in each row for particular set

spores. The population of vegetative cells reduced drastically after 20 min of exposure to UV radiation, but at the same time the spore count was15 times higher than their vegetative cells. Reduction in population of vegetative cells under UV radiation was mainly due to the interference of UV radiation with the transcription and translation of nucleic acid. Higher resistance (5 to 50 times) of spores of various Bacillus species against UV radiation compared to their vegetative cells was also reported by Stelow (2001). The increasing UV resistance in spores is primarily because of difference in the UV photochemistry of DNA in spores, and the efficient and relatively infallible repair of the novel photoproduct formed by UV light in spore DNA (Nicholson et al., 2000). The prime UV photoproduct formed in DNA of vegetative cells and spores by 254-nm UV irradiation is a cis (syncyclobutane type thymine dimer) and SP (thymine adduct 5- thyminyl-5, 6-dihydrothymine), respectively (Nicholson et al., 2000). This unique structure formed in spores provides the resistance power to the spores towards UV radiation.

A wide difference was observed in the minimum inhibitory concentration (MIC) of antibiotics for the vegetative cells of $B$. pumilus compared to their respective endospores (Table 3 ). The vegetative cells of $B$. pumilus could withstand very little concentration of antibiotics; therefore; the corresponding MIC value was low. Among the strains of $B$. pumilus, MTCC 5574 recorded moderately higher MIC value in amoxicillin (30 $\left.\mathrm{\mu g} \mathrm{ml}^{-1}\right)$ and streptomycin $\left(60 \mathrm{\mu g} \mathrm{ml}^{-1}\right)$, whereas MTCC 5575 recorded comparatively higher MIC values in ampicillin $\left(8 \mu \mathrm{g} \mathrm{ml}^{-1}\right)$ and tetracycline $\left(10 \mu \mathrm{g} \mathrm{m}^{-1}\right)$. On the other hand, at the highest concentrations $\left(240 \mathrm{\mu g} \mathrm{m}^{-1}\right)$ used for each of the antibiotics under 
study, the growth of endospores of $B$. pumilus was found unaffected, indicating the fact that the spore formation facilitated the life form regardless of the presence or absence of antibiotics. This might be due to less permeability of the outer and inner membranes of spores (Paredes-Sabja et al., 2011; Leggett et al., 2012).

In laboratory trial, it was observed that spores germinate into their vegetative forms under favourable condition and secrete extracellular pectinolytic and xylanolytic enzymes, indicated by higher CFU counts on the pectin agar as well as xylan agar plates (Table 1) during the entire retting period. The test sets (Set 1 and Set 2) were inoculated with endospores. The viable cell count increased significantly and reached up to $10^{10} \mathrm{cells} \mathrm{ml}^{-1}$ (Set 1 ) and

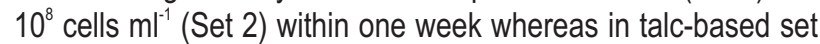
(Set 3) the CFU count was $10^{7} \mathrm{ml}^{-1}$ (Table 1). Higher CFU in Set 1 and Set 2 compared to Set 3 was due to the higher germination of endospores of Bacillus pumilus to their vegetative cells immediately after getting the suitable environment in terms of nutrients etc. Higher germination of Bacillus spp. in response to nutrients was also reported by Wang et al. (2015). The CFU counts of pectinolytic and xylanolytic bacteria in Set 1 after 12 days of retting were $52 \times 10^{13}$ and $67 \times 10^{13}$ per ml of retting water, respectively, which was significantly higher as compared to Set 2 and Set 3 at the same time (Table 1). The presence of higher CFU in Set 1 was also reflected in its corresponding rise in polygalacturonase and xylanase enzyme activities compared to that of Set 2 and Set 3. On day 7, Set 1 showed significantly higher polygalacturonase (48.55 $\left.\mathrm{U} \mathrm{ml}^{-1}\right)$ and xylanase (18.49 $\left.\mathrm{U} \mathrm{ml}^{-1}\right)$ enzyme activity over Set $2\left(28.09 \mathrm{U} \mathrm{ml}^{-1}\right.$ and $\left.8.09 \mathrm{U} \mathrm{ml}^{-1}\right)$ and Set 3 $\left(11.56 \mathrm{U} \mathrm{ml}^{-1}\right.$ and $\left.3.47 \mathrm{U} \mathrm{ml}^{-1}\right)$. The higher polygalacturonase and xylanase activities in Set 1 on day 7 might have been due to the persistence of significantly larger copy number in spore suspensions after six months of preparation. The Set 1 also showed highest polygalacturonase and xylanase activity on day 12, which was $104.04 \mathrm{U} \mathrm{ml}^{-1}$ (1.76 and 3.33 times higher than Set 2 and Set 3 ) and $50.86 \mathrm{U} \mathrm{ml}^{-1}$, respectively (1.69 and 3.99 times higher than Set 2 and Set 3 )

In large scale field study with 18-month-old endospores and talc based formulation, the CFU number of pectinolytic bacteria reached up to $25 \times 10^{14} \mathrm{ml}^{-1}$ in Set 1 and $9 \times 10^{13} \mathrm{ml}^{-1}$ in Set 2 after 12 days of retting from the initial value of $15 \times 10^{3} \mathrm{ml}^{-1}$ and $12 \mathrm{x}$ $10^{3} \mathrm{ml}^{-1}$, respectively. Similarly, the CFU count of xylanolytic bacteria reached up to $17 \times 10^{9} \mathrm{ml}^{-1}$ and $9 \times 10^{7} \mathrm{ml}^{-1}$ from the initial value of $32 \times 10^{2}$ and $27 \times 10^{2} \mathrm{ml}^{-1}$, respectively, after 12 days of retting in Set 1 and Set 2. However, in Set 3, the CFU number of pectinolytic and xylanolytic bacteria reached only up to $13 \times 10^{8}$ and $15 \times 10^{6} \mathrm{ml}^{-1}$ after 12 days of retting because of their significantly lower initial CFU counts. This was also reflected in the polygalacturonase and xylanase activity of three sets (Fig 1a, 1b). There was a sharp increase in polygalacturonase and xylanase activity throughout the retting period in Set 1 and 2 compared to

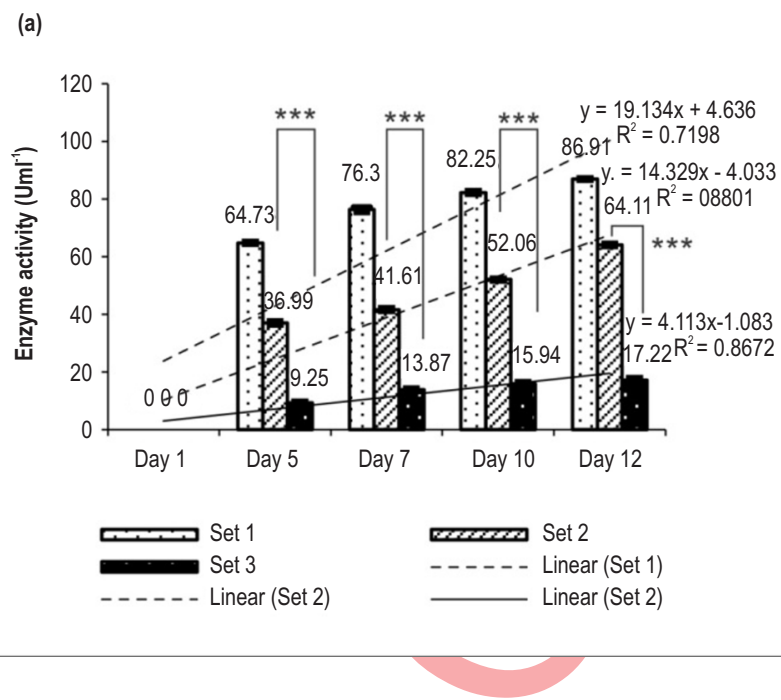

(b)

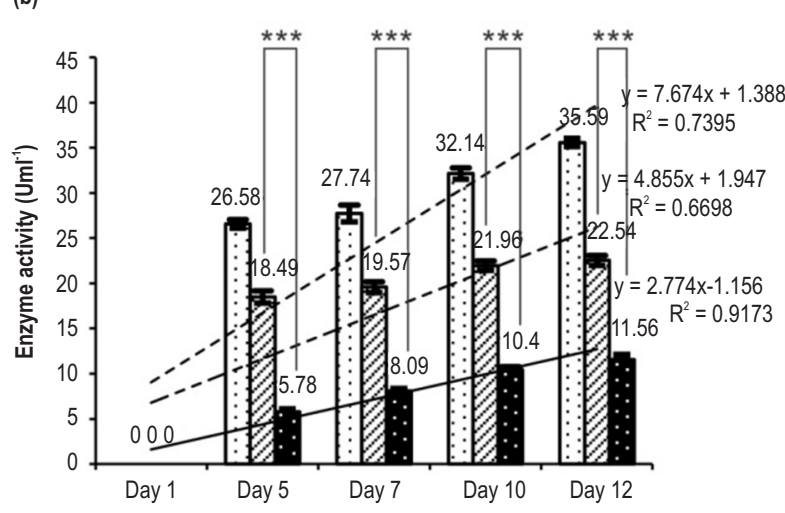

Fig. 1 : (a) Changes in polygalacturonase activity during large scale retting: Test results were recorded on $5^{\text {th }}, 7^{\text {th }}, 10^{\text {th }}$ and $12^{\text {th }}$ day after inoculation. Although in all three sets a gradual increase in enzyme activity had been observed as days passed, but the most steep increase was detected in case of set 1 , as perceived from the straight line equation (slope, $m=+19.134$ ). The slowest change in enzyme activity was detected in set 3 (slope, $m=+4.113$ ). The set 2 scored much closer to the set 1 (slope, $m=+14.329)$. Set 2 was found to show significantly higher $(* * *=p<0.001)$ polygalacturonase activity as compared to set 3 . From this, it was also evident that set 1 would definitely bear a significant difference with set 3 ;

(b) Changes in xylanase activity during large scale retting: A similar pattern of enzyme activity increment with time could be observed in xylanase activity assay as well. Here also, the most steep increase was detected in case of set 1 (slope, $m=+7.674$ ) and the slowest change in xylanase activity was noticed in set 3 (slope, $m=+4.855$ ). Though Set 2 slope was much lesser than set 1 , the set 2 was found to show significantly higher ${ }^{* * *}=p<0.001$ ) polygalacturonase activity as compared to set 3 . Here also it was evident from the graph that set 1 would definitely bear a significant difference with set 3 . Data used as mean \pm SD of enzyme activity $\left(\mathrm{Uml}^{-1}\right)$. 
Table 3 : Effect of pH, temperature, UV radiation and antibiotics on endospores and vegetative cells of $B$. pumilus

\begin{tabular}{|c|c|c|c|}
\hline Sample & $\mathrm{pH} 3$ & pH 10 & pH 12 \\
\hline MTCC 5573 & 0 & $147 \pm 6$ & 0 \\
\hline MTCC 5574 & 0 & $152 \pm 5$ & 0 \\
\hline MTCC 5575 & 0 & $159 \pm 8$ & 0 \\
\hline MTCC 5573 spore & $>300$ & Lawn & $>300$ \\
\hline MTCC 5574 spore & $>300$ & Lawn & $>300$ \\
\hline MTCC 5575 spore & $>300$ & Lawn & $>300$ \\
\hline Sampie & $60^{\circ} \mathrm{C}$ & $80^{\circ} \mathrm{C}$ & $100^{\circ} \mathrm{C}$ \\
\hline MTCC 5573 & TNTC & $145 \pm 6.06$ & $25 \pm 1.83$ \\
\hline MTCC 5574 & TNTC & $152 \pm 2.58$ & $21 \pm 1.41$ \\
\hline MTCC 5575 & TNTC & $137 \pm 4.69$ & $18 \pm 2.58$ \\
\hline MTCC 5573 s.pore & Lawn & Lawn & $>300$ \\
\hline MTCC 5574 spore & Lawn & Lawn & $>300$ \\
\hline MTCC 5575 spore & Lawn & Lawn & $>300$ \\
\hline \multirow[t]{2}{*}{ Sample } & & Time of exposure & \\
\hline & $10 \mathrm{~min}$ & $15 \mathrm{~min}$ & $20 \mathrm{~min}$ \\
\hline MTCC 5573 & $247 \pm 5.35$ & $192 \pm 7.83$ & $18 \pm 6.48$ \\
\hline MTCC 5574 & $238 \pm 6.22$ & $173 \pm 5.83$ & $17 \pm 5.6$ \\
\hline MTCC 5575 & $256 \pm 5.48$ & $212 \pm 6.98$ & $15 \pm 4.69$ \\
\hline MTCC 5573 spore & TNTC & $>300$ & $272 \pm 11.22$ \\
\hline MTCC 5574 spore & TNTC & $>300$ & $259 \pm 10.49$ \\
\hline MTCC 5575 spore & TNTC & $>300$ & $282 \pm 7.61$ \\
\hline \multirow[t]{2}{*}{ Sample } & \multicolumn{3}{|c|}{ Antibiotics (MIC $\mu \mathrm{g} \mathrm{ml}^{-1}$ ) } \\
\hline & Ampicillin & Amoxycillin & Streptomycin \\
\hline MTCC 5573 & 2 & 0.01 & 10 \\
\hline MTCC 5574 & 2 & 0.1 & 60 \\
\hline MTCC 5575 & 8 & 0.01 & 30 \\
\hline \multicolumn{4}{|l|}{ MTCC 5573 spore } \\
\hline \multicolumn{4}{|l|}{ MTCC 5574 spore } \\
\hline MTCC 5575 spore & & & \\
\hline
\end{tabular}

Values are mean of replicate \pm SD; TNTC= Too numerous to count, MIC = Minimum inhibitory concentration

Set 3, and the enzymatic activities were higher several times compared to Set 3 at different sets of time. Higher polygacturonase and xylanase in Set 1 and Set 2 was due to higher copy number of pectinolytic and xylanolytic microbes at every stage of retting, compared to Set 3 .

In laboratory scale study, with 6-month-old endospores and talc based formulation, the retting of jute was completed in 10 and 12 days for Set 1 and Set 2, whereas the retting of Set 3 was accomplished in 15 days (Table 2). The fibre recovery was also higher in case of endospores than talc based formulation. In Set 1 , fibre recovery was $7.2 \%$ which was $16.1 \%$ higher over Set 3. The fibre strength was very high in case of Set 1 (27.8 gtex $\left.{ }^{-1}\right)$ which was $10.75 \%$ higher over Set 3 (25.11 gtex $\left.^{-1}\right)$. In case of large scale field study with 18-month-old endospores and talc based formulation, the retting of jute was completed in 10 and 12 days with two different doses of endospores and in 21 days with talc based formulation (Table 2). The fibre recovery was $7.3 \%$ in case of Set 1 , while it was only $5.5 \%$ in case of talc based formulation. The significantly lower CFU counts and enzymatic activities during retting (Fig. 1a, b) in case of talc based formulation led to higher retting duration, and subsequently lower fibre recovery compared to endospores. This was also reflected in strength and fineness of fibre.

The lower the retting duration, the higher was the fibre recovery, and consequently higher fibre strength was observed in case of retting with endospores as compared to the talc based formulation. The reason behind this might be the sustenance of higher copy number (refers to the CFU count), significantly higher polygalacturonase and xylanase activities during retting with endospores as shown in Table 1 and Fig. 1a, b. In a comparative 
study of jute retting, use of talc based microbial formulation resulted in higher CFU count, polygalacturonase and xylanase activities compared to conventional retting without any microbial formulation (Das et al., 2018).

It can be concluded from the study that in future endospores of Bacillus pumilus can be used in place of talc based microbial formulation for higher shelf life of the product, faster retting and better fibre quality of jute. The use of endospores would also reduce the production cost and facilitate the use of left out formulation in the succeeding years for faster retting because of its resistance to environmental stresses.

\section{Acknowledgment}

Authors are highly grateful to the Director, ICAR-Central Research Institute for Jute and Allied Fibres, Barrackpore, Kolkata for providing necessary facilities and financial support for the study.

\section{References}

Atrih, A. and S.J. Foster: Analysis of the role of bacterial endospore cortex structure in resistance properties and demonstration of its conservation amongs species. J. Appl. Microbiol., 91, 364-372 (2001).

Bandyopadhyay, S.B. and N.G. Sinha: An airflow method for the determination of the fibre fineness of jute and mesta. J. Text. Inst., 59, 148-151 (1968).

Banik, S., M.K. Basak and S.C. Sil: Effect of inoculation of pectinolytic mixed bacterial culture on improvement of ribbon retting of jute and kenaf. J. Nat. Fibers., 4, 33-50 (2007).

Cazemier, A.E., S.F.M. Wagenaars and P.F. Steeg: Effect of sporulation and recovery medium on the heat resistance and amount of injury of spores from spoilage bacilli. J. Appl. Microbiol., 90, 761-770 (2001).

Das, B., K. Chakrabarti, S. Ghosh, B. Majumdar, S. Tripathi and A. Chakraborty: Effect of efficient pectinolytic bacterial isolates on retting and fibre quality of jute. Ind. Crops Prod., 36, 415-419 (2012).

Das, S., B. Majumdar and A.R. Saha: Biodegradation of plant pectin and hemicelluloses with three novel Bacillus pumilus strains and their combined application for quality jute fibre production. Agric. Res., 4,354-364 (2015).

Das, S., B. Majumdar, A.R. Saha, S. Sarkar, S.K. Jha, S.K. Sarkar and R. Saha: Comparative study of conventional and improved retting of jute with microbial formulation. Proc. Natl. Acad. Sci., India, Sect. B Biol. Sci., 88, 1351-1357 (2018).

Hornstra, L.M., A.T. Beek, J.P. Smelt, W.W. Kallemeijn and S. Brul: On the origin of heterogeneity in (preservation) resistance of Bacillus spores: input for a 'systems'analysis approach of bacterial spore outgrowth. Int. J. Food Microbiol., 134, 9-15 (2009).
Leggett, M.J., G. Mcdonnell, S.P. Denyer, P. Stelow and Jo-Y. Maillard: Bacterial spore structures and their protective role in biocide resistance. J. Appl. Microbiol., 13, 485-498 (2012).

Mahdi, S.S., G.I. Hassan, S.A. Samoon, H.A. Rather, S.A. Dar and B. Zehra: Bio-fertilizers in organic agriculture. J. Phytol., 2, $42-54$ (2010).

Majumdar, B. and S. Satpathy: Improved retting technology of jute for quality fibre production. Indian Fmg., 64, 18-20 (2014).

Majumdar, B., S. Das, A.R. Saha, H. Chowdhury, D.N. Maitra and M.N. Saha: Improved retting of jute and mesta with microbial formulation.Central Research Institute for Jute and Allied Fibres (ICAR), Barrackpore, Kolkata, India, Bull. No. 4/2013, pp. 1-31 (2013).

Mohammadi, K. and Y. Sohrabi; Bacterial biofertilizers for sustainable crop production: A review. ARPN J. Agric. Biosci., 7, 307-316 (2012).

Manisha, R., M.V. Uma and V. Krishna murthy: Partial purification and characterization of Baciilus pumilus xylanase from soil source. Kat. Univ. J. Sci. Eng. Technol., 5, 137-148 (2009).

Nicholson, W.L. and P. Setlow: Sporulation, germination and outgrowth In: Molecular Biological Methods for Bacillus (Eds.: C.R. Harwood and S.M. Cutting). JohnWiley and Sons, Chichester, England, pp. 391-450.(1990).

Nicholson, W.L., N. Munakata, G. Horneck, H.J. Melosh and P. Stelow: Resistance of Bacillus endospores to extreme terrestrial and extraterrestrial environments. Microbiol. Mol. Biol. R., 64, 548-572 (2000).

Paredes-Sabja, D., P. Stelow and M.R. Sarker: Germination of spores of Bacillus and Clostridiales species, mechanisms and proteins involved. Trends Microbiol., 19, 85-94 (2011).

Phutela, U., V. Dhuna, S. Sandhu and B.S. Chadha: Pectinase and polygalacturonase production by a thermophillic Aspergillus fumigatus isolated from decomposting orange peels. Braz. J. Microbiol., 36, 63-69 (2005).

Pindi, P.K. and S.D.V. Satyanarayana: Liquid microbial consortium- A potential tool for sustainable soil health. J. Biofert. Biopest., 3, 124 (2012).

Roy, G., G.K. Bhattacharya, S. Sengupta and M. Mukherjee: A new electronic fibre bundle strength tester for jute. J. Inst. Eng. (India), 89, 10-13 (2009).

Sella, S.R.B.R., L.P.S.Vandenberghe and C.R. Soccol: Life cycle and spore resistance of spore forming Bacillus atrophaeus. Microbiol. Res., 169, 931-939 (2014).

Stelow, P.: Resistance of spores of Bacillus species to ultraviolet light. Environ. Mol. Mutagen., 38, 97-104 (2001).

Stelow, P.: I will survive: DNA protection in bacterial spores. Trends Microbiol., 15, 172-180 (2007).

Thirumurugan, D. and S. Asha: Spore forming bacterial biofertilizer for phosphate solubilization and bio-control agent. Int. Sci. J., 1, $51-58(2010)$.

Wang, S., J. R. Faeder, P. Setlow and Yong-ging Li: Memory of germinant stimuli in bacterial spores. mBio, 6, e01859-15 (2015). 